\title{
Have the Guests Perceived Superior Value?
}

\author{
Levyda \\ Management Department, Sahid University \\ Jl. Prof. Dr. Soepomo No.84, Jakarta Selatan 12870, Indonesia \\ levyda@usahid.ac.id; levyda_mm@yahoo.co.id
}

Received: $17^{\text {th }}$ June 2017/ Revised: $12^{\text {th }}$ September 2017/ Accepted: $15^{\text {th }}$ September 2017

How to Cite: Levyda. (2017). Have the Guests Perceived Superior Value? Binus Business Review, 8(3), 199-206 http://dx.doi.org/10.21512/bbr.v8i3.3683

\begin{abstract}
This research aimed to describe guests' perceived value by using a multidimensional approach. From previous research, guests' perceived value consisted of some functional value, emotional value, and social value. Based on guest experience, and functional value consisted of physical evidence, guest room, food and beverage, hotel staff, and price. This research was conducted in four-star hotels in Jakarta. The respondents were the guests who had stayed in four-star hotels. The number of the respondent was 405 . The data were obtained by using selfadministered questionnaires. This research shows that guests have not perceived superior value. Some of the values and the necessary efforts need to be improved.
\end{abstract}

Keywords: perceived value, superior value, multidimensional, hotel

\section{INTRODUCTION}

Jakarta is the most important province for the establishment of star rated hotel. The establishment of star rated hotel in Jakarta grows gradually. In 2010, the number of the star rated hotel in Jakarta was 165 . In 2011 , the number grew $4,84 \%$, and the following year, it grew 2,8\%. From 2012 to 2013 , the number grew $3,3 \%$, and in the next period, it had $17,9 \%$ of growth (Badan Pusat Statistik, 2010 \& 2012)

In 2014, there were 217 star rated hotels in Jakarta. $35,48 \%$ are categorized as the three-star hotel, $22,12 \%$ as the two-star hotel, $19,82 \%$ as the four-star hotel, and $11,98 \%$ as the five-star hotel. The four-star hotel has the most room, followed by five-star hotel and three-star hotel. In 2014, the occupancy rate of the star rated hotel in Jakarta was less than $60 \%$. The occupancy rate in the five-star hotel was $46,19 \%$. The highest occupancy was in the two-star hotel, which was $56,67 \%$. The four-star hotel and three-star hotel were in the second and third position. Their occupancy rates were $54,89 \%$ and $53,67 \%$ respectively. Thus, almost $40 \%$ of room capacity was unoccupied. (Badan Pusat Statistik Provinsi DKI Jakarta, 2014).

Services cannot be stored so when the $40 \%$ is unoccupied, and hotels lose the opportunity to earn revenue. This encourages hotels to perform various tactics to increase revenue. Discount price is a tactic which is frequently used (Bojanic, 1996). However, this tactic can degrade the brand image and the income of the hotel. Therefore, another better strategy is needed. Bowen and Shoemaker (2003) suggested that increasing the customer value could increase guest loyalty. Meanwhile, Ravald and Grönroos (1996) argued that to build long-term relationship, the company should provide superior value. Superior value can also be a competitive advantage (Woodruff, 1997; Slater \& Narver, 1994). To generate a superior value, a hotel should assess the value continuously.

According to Day (1999), value assessment can be utilized as a guideline for prioritizing and reshaping value. Reshaping value requires investment. Craven and Piercy (2009) said that the assessment could be used to identify the need for the new product and improve some business process. Therefore, it reduced the gap between expectation and fact.

Value is the core concept of marketing. In marketing, there some terms using the word "value" namely customer value, perceived value, and customer perceived value so it needs to be clarified. Zeithaml (1988) defined that value as low price, whatever people wanted in product, the quality people got for 
the price they pay, and what people got for what they gave. Similarly, Anderson and Narus (1998) said value as the benefit or "something worth" for the price paid by a buyer. Then, Wu and Liang (2009) agreed that value as "the worthiness" of the ability to meet the criteria which were derived from the product. Value is also defined as the condition that is more preferred by consumers (Solomon, 2011; Woodal, 2003) based on certain standards (Sanchez et al., 2006) such as monetary standard (Boztepe, 2007). It may also mean the ability to offer satisfactory benefits (Haksever et al., 2004).

Customer value can be viewed from the perspective of the company and the consumer. From a company perspective, customer value is defined as the value obtained from customers coming from an increasing in sales (Payne \& Holt, 2001), return and customer turnover (Huber \& Herrmann, 2000; Slater et al., 1994). From a customer perspective, customer value is the result of customer evaluation (Holbrook, 2006; Sánchez-Fernandez \& Iniesta-Bonillo, 2006; Haemoon, 2000; Woodruff, 1997), cognitive (Zeithaml, 1998) or cognitive and affective (Sánchez-Fernandez \& Iniesta-Bonillo, 2006). Then, customer value, perceived value and customer perceived value are the same concept (Chen \& Dubinsky, 2003). Consumers act and react subjectively base on their perception and do not base on objective conditions (Schiffman and Kanuk, 2010). Consequently, the value of the products should be measured based on their perception. Therefore, this research uses the concept of perceived value. According to Zeithaml (1988), perceived value was a customer's overall assessment of the utility of a product based on perceptions of what was received and what was given. Zeithaml (1988), Bojanic (1996),
Parasuraman and Grewal (2000), Cronnin et al. (2000), and Tam (2004) measured perceived value by comparing benefit and sacrificial components.

Moreover, consumer behavior can be viewed from a traditional view and a hedonic view (Hirschman \& Holbrook, 1982). In the traditional view, consumers buy a product because of the utility. Meanwhile, the hedonic view expands the traditional view. The consumer buys because of the objective and subjective goals (Hirschman \& Holbrook, 1982). The research using hedonic views defines the values as multi-dimensional constructs and measures perceived value concepts with multidimensional measurements (Sweeney \& Soutar, 2001; Sanchez et al., 2006; Williams \& Soutar, 2009). They adopted the theory of consumptions value developed by Sheth et al., (1991) to identify the types of values. In addition, Gallarza et al. (2006) and Sánchez-Fernandez et al. (2009) used the typology of value theory developed by Holbrook (2006).

Consumers buy products based on two basic reasons, namely instruments or utilitarian and affective or hedonic (Batra \& Ahtola, 1991). This research uses a multidimensional approach. Essentially, the service is delivered to the guest experience which starts from the reservation process, arrival, registration, food \& beverage, room facilities, and other facilities described in the service blueprint in Figure 1. Based on the guest experience, the functional value consists of the physical environment, the functional value of the guestrooms, the functional value of hotel staff service, the functional value of food and beverages, and functional value of the price.

Physical environments enjoyed by guests are location, interior and exterior, design, ornaments,

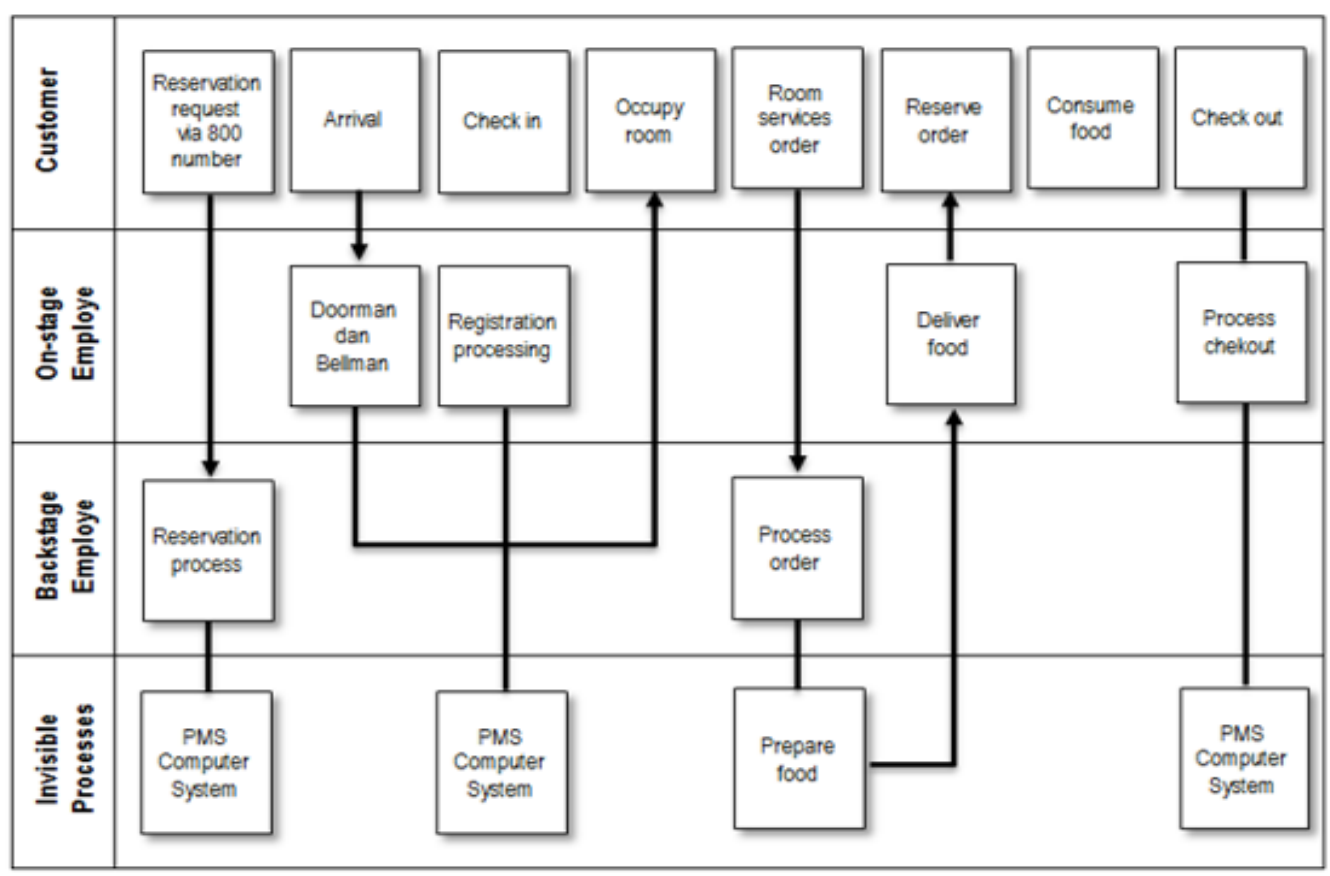

Figure 1 Service Blueprinting

(Source: Reid \& Bojanic, 2010) 
and facilities in the lobby. Meanwhile, the guest room facilities enjoyed by guests are bed, bathroom, electronic equipment, furniture and ornaments, and guest supplies. Food and beverage facilities are the food and beverage, tableware, and dining room, and services of the hotel staff in the lobby, restaurant, and guestrooms are measured by their performance and appearance. All things enjoyed by guests starting from check in to check out are paid for a single price of the room. The physical environment, guestroom, food and beverage are measured by capacity, functionality, or performance of physical environment, or facilities and price. Meanwhile, hotel staff is measured based on appearance and performance (Sheth et al., 1991; Sweeney \& Soutar, 2001; Smith \& Colgate, 2007).

Batra and Ahtola (1990) added that other than utility, consumers bought the service because they wanted to get affective or hedonic aspects which could be perceived by the senses. Emotional value is the positive feeling arising during a stay at a hotel (Smith \& Colgate, 2007; Sheth et al., 1991; Sweeney \& Soutar, 2001; Barsky \& Nash, 2002). Moreover, social value is an appreciation that is expected from others because of staying in a hotel (Sirgy, 1982; Sheth et al., 1991; Sweeney \& Soutar, 2001; Miladian \& Sarvestani, 2012; Hosany \& Martin, 2012).

This research aims to test the hypothesis of the superior value perceived by the guests and describe them. Normatively, guests want the highest value, so the hypothesis of this research is as follows.

\section{H1 : Guests in four-star hotels have perceived superior value.}

\section{METHODS}

To measure guests' perceived value, this research uses the descriptive method. Guests' perceived value is the data interval. Thus, the statistical tools used are the range, average, and standard deviation for the data in the form of interval data (Maholtra, 2012, Sekaran \& Bougie, 2010).

Guests' perceived value is measured by the seven dimensions. Those are functional values of the physical environment, the guestrooms, the hotel staff services, the food and beverages, the price, emotional value, and social value. The functional value of the physical environment is measured by nine indicators. Then, the functional value of the guestroom is measured by seven indicators, the functional value of the foods and beverages has five indicators. The functional value of the hotel staff services and price are measured by seven indicators and four indicators respectively. The emotional value is nine indicators, and the social value is three indicators.

The level of respondents' assessment is one to six. Six means that the guests perceive a superior value. Five is that the guests perceive a high value and four is the guests perceive sufficient value. Meanwhile, three means the guests perceive less value and two is when the guests perceive low value. One means the guests perceive inferior value.

The limit of acceptance or rejection of the hypothesis is obtained from the difference between the highest score and the lowest score (6-1). Then, from calculation the interval length, it obtains the formula or (maximum score), and the result is 0,83 . The length of interval and category can be seen in Table 1 .

Table 1 Length of Interval and Category

\begin{tabular}{cc}
\hline Length of interval & Category \\
\hline $1,00-1,83$ & The lowest value \\
$1,83-2,65$ & Low value \\
$2,66-3,48$ & Less value \\
$3,49-4,31$ & Sufficient value \\
$4,32-5,14$ & High value \\
$5,15-6,00$ & The highest value \\
\hline
\end{tabular}

The primary data are collected by using questionnaire. Questionnaires are distributed in two ways, during check-in and in the guestrooms. Submission of a questionnaire is carried out selfadministratively. There are 405 questionnaires which are feasible to be processed. $55,31 \%$ of respondents are male, and $44,69 \%$ are female. Then, $37,78 \%$ of respondents are $21-30$ years old, $28,64 \%$ are $31-40$ years old, and $15,31 \%$ are $41-50$ years old.

The descriptive hypothesis is examined by student t-test (Cooper \& Schindler, 2011). The criteria for rejection or acceptance of the null hypothesis are at the $5 \%$ of significance level and degree of freedom n-1.

\section{RESULTS AND DISCUSSIONS}

The hypothesis proposed is the left-side hypothesis. The average value of the alternate hypothesis is smaller than the minimum limit. The result of student t-test obtains the t-value about $-23,455$. The value is higher than t-table $(-1,645)$, so the hypothesis null is rejected and accepted the alternate hypothesis.

The functional value of the physical environment (FV-PE) is measured by three groups of indicator, namely location, design and décor, and upkeep (Levyda, 2017). The location is measured by ease of reaching hotel location, closeness to business centers, and traffic movement. Moreover, design and décor are measured by hotel exterior, hotel interior, décor, furniture, ornaments in the lobby and corridors, and facilities in the lobby and corridors.

The perceived value of the location is varied. Guests' perceived the high value because of the closeness of the hotel to the shopping center and offices. Some hotels in Jakarta are established in a free-standing location, and other hotels are in the mall or office building as the host point of distribution. However, the perceived value of traffic movement at 
the site is considered as low value. Traffic movement is beyond the hotel's control and difficult to predict for a rapidly growing city. Thus, the location should be the primary consideration in the feasibility of research in the hotel.

The perceived value that comes from the interior design of the hotel is very diverse because of the diversity of interior design of the hotel. Guests do not like the design that has many room insulations. It is because it makes them difficult to search the room and it looks narrow. Guests also perceive a sufficient value for design and decor. However, the age of buildings and facilities should be noted for the renovation or restoration. Hotel upkeep can extend the lifetime and deliver the value to guests.

Most of the four-star hotels in Jakarta are business or convention hotels. Koh (2008) stated that business or convention hotels should be positioned as a workplace or an escape from the office routine, so the focus was on lobbying and food and beverage services. To enhance customer value, it was suggested the hotel provided elegant and comfortable atmosphere and sophisticated amenities. For corridor ornaments, Koh (2008) emphasized on color and lighting. The bottom color should be darker than the top. Good lighting allowed guests to find room numbers and to create a safe and comfortable atmosphere.

In addition, to increase hotel value, hotel manager has some option in upkeeping or maintaining hotel facilities. According to Richard et al. (2000), there are two types of upkeep or maintenance, namely planned and unplanned maintenance. Planned maintenance consists of two types of maintenance. Those are predictive maintenance and routine preventive maintenance. Meanwhile, unplanned maintenance is a reactive maintenance. In this maintenance, there are only minimal routine improvements that aim to utilize the facilities until it is no longer usable. Often, cost and investment considerations are more important than perceived value, so many hotels choose unplanned maintenance than planned maintenance. The result of functional value of the hotel physical environment is described in Figure 2.

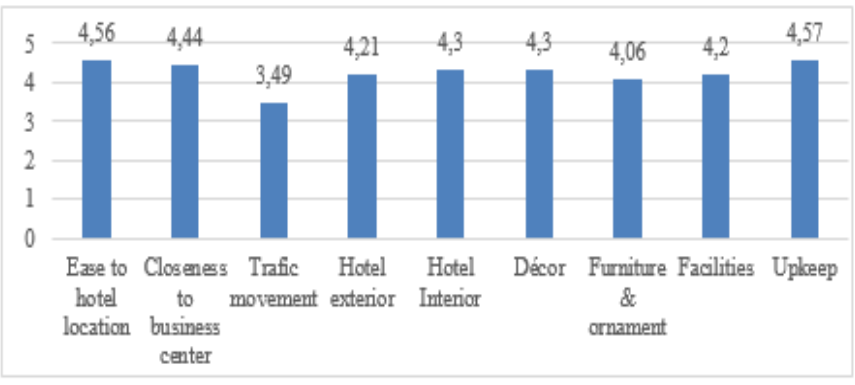

Figure 2 Functional Value of Physical Environment

Next, it is functional value of guestroom. Guestroom is the core of a product. The luxury of the hotel is indicated by all things in the guest rooms.
The functional value of guestroom is measured by six indicators. There are the room decor, furniture and ornaments of rooms, cleanliness of beds, guest supplies, cleanliness of bathrooms, electronic equipment (Levyda, 2017). Guests perceive a sufficient value for the guestroom.

The hotel also offers electronic equipment, which varies in number, type, and sophistication. This determines the value felt by guests. The challenges in electronic equipment are the demand from guests and the lifetime of electronic equipment. The key to increase the perceived value is the planning of maintenance, replacement, and investment of electronic equipment. Moreover, the complaints which are often said by guests are the cleanliness of linen. It is in the form of rust stains, smell, dull colors, and the folds on bed creating the untidy impression. Ideally, linen is washed 160 to 200 times, and the replacement of linen should be performed in every 7-12 months. The economic life of linen is two years (Jones, 1995). The functional value of guestroom is described in Figure 3.

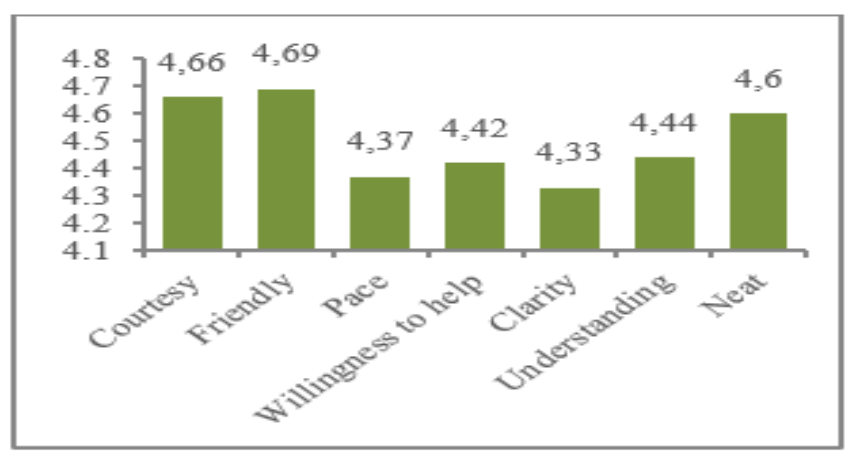

Figure 3 Functional Value of Guestroom

Moreover, there is functional value of food and beverages. Hotels produce goods and services. The value of food and beverage is one of the important functional values. It is measured by the varied menu, delicious food and beverages, attractiveness of the course, hygiene of food \& beverages, and comfort of the dining room (Levyda, 2017). Although the guests already perceive the high value for the various menu and delicacy, there is a need to improve this value. The hotels should have a wide range of menu choices. For example, it can be menu ethnicity associated with specific cultures like Indonesian cuisine, Oriental cuisine, or Western cuisine. Some hotels focus on specialty foods associated with certain substances like seafood. Continual research and improvement should be made to ensure that the menu and the delicacy of the food match the tastes of the consumers. Then, to show food and beverage hygiene, hotels can choose open or transparent kitchen strategy. The open kitchen is perceived as clean and healthy, and entertainment positively ( $\mathrm{Wu}, 2013)$. These functional values are illustrated in Figure 4. 


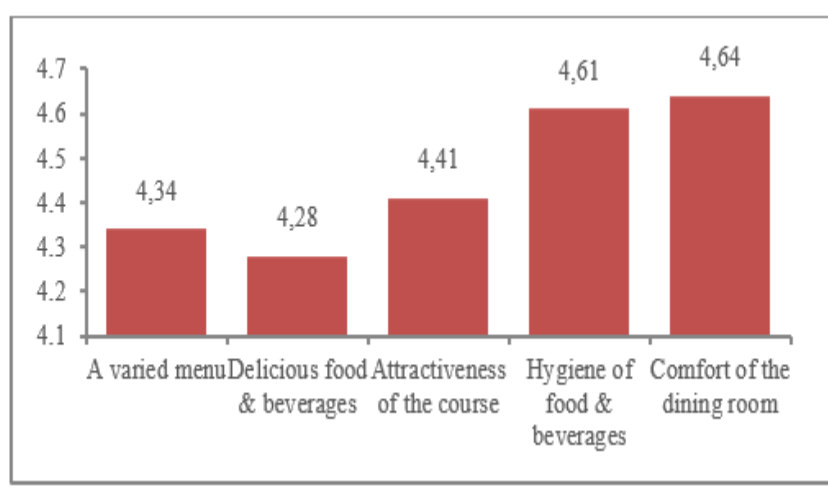

Figure 4 Functional Value of Food and Beverages

Next, it is functional value of hotel staff. The four-star hotel is a full-service hotel, so the services of the front-liner staff are very important. Front liner staff interacts directly with guests. In such interaction, guests expect the courtesy of the employees, friendliness, the pace of work, willingness to help, clarity in communication, understanding individual's needs, and neat appearance (Levyda, 2017).

With the assessment scale of one to six, it is concluded that the perceived value of hotel staff is sufficient. The pace of work and clarity of information conveyed by the staff are slightly lower than the other indicators. The pace of work is determined by several things such as standards and work procedures, and individual characteristics. Meanwhile, clarity of information is determined by the language skills, especially English or other foreign languages. Then, the capability can be improved by performing intensive training.

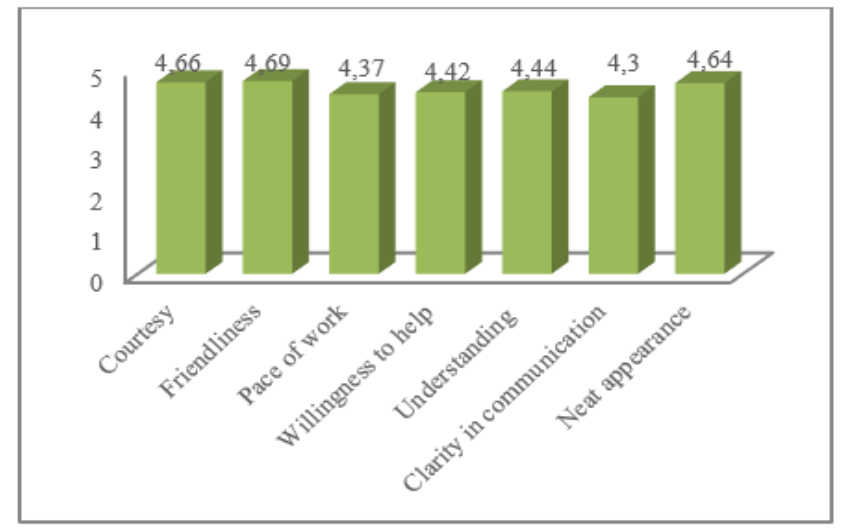

Figure 5 Functional Value of Hotel Staff

Next, price in the hotel is for a set of services including the use of certain types of rooms, employee service, certain facilities in public areas, and breakfast. Hotel price is relatively difficult to determine by cost approach as it requires the use of a value approach. On the value approach, value means cheap. As the price reflects the quality, it also reflects the benefits received. It is the compatibility between what is received and what is sacrificed (Zeithaml, 1988). Therefore, the functional value of price is assessed by comparing price and amenities, price and services, and reasonable and economical price (Levyda, 2017). The guests assess that the price is worth for the facilities and services received. Besides that, the price is reasonable and quite economical. Overall, the guests perceive a sufficient value for the price.

Chen and Rothschild (2010) highlighted Kotler's statement in a hotel context. Price was the only element of marketing mix that produced revenue, so pricing was a strategic issue in marketing. Although guests perceived sufficient value, hotel should increase it. In addition, Shoemaker (2003) suggested some price tactics and strategies namely seasonal rate, yield management system (revenue per available room), revenue management (revenue per available customer), value pricing (price based on value received), and price bundling (price based on customer knowledge). Similarly, Akaegbu (2013) concluded that many literatures recommended the price based value. Guests paid based on their perceptions of the value offered by the hotel. Therefore, the measurement of the perceived value of the guests is very important. The result of price value is in Figure 6.

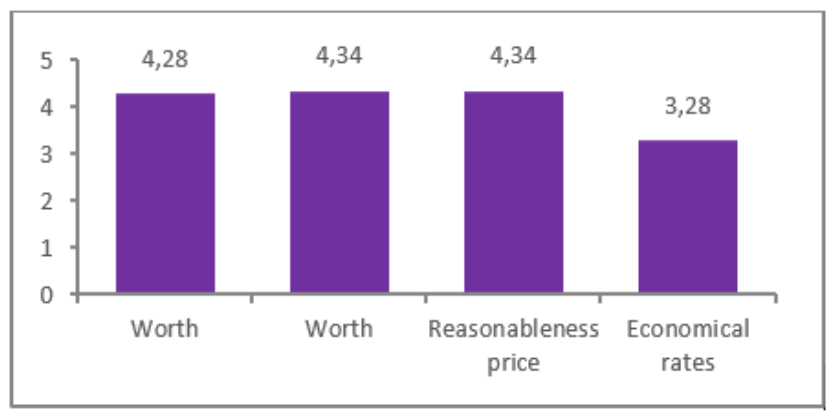

Figure 6 Functional Value of Price

In emotion value, guests' attitude in the future is determined by hedonic consumption. Then, positive emotion of the guests is measured by a comfortable, appreciated, relaxed, accepted, proud, practical, secure, fascinated, and pleased sense (Barsky \& Nash, 2002; Levyda, 2017). Overall guests perceive high emotion value, but they are not too proud and amazed. It can be seen in Figure 7.

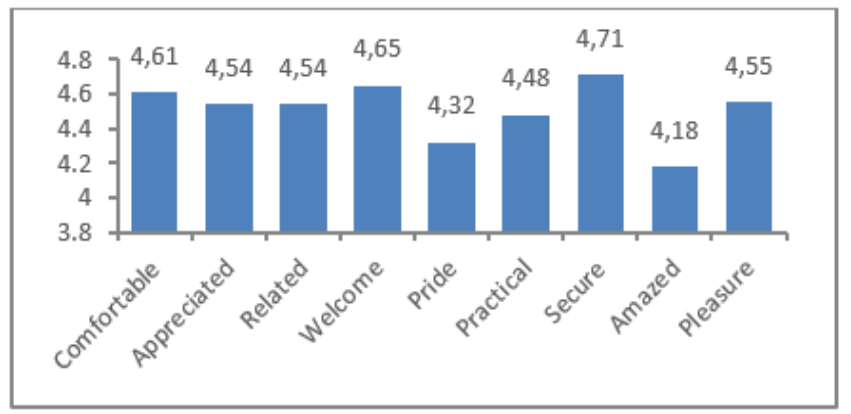

Figure 7 Emotion Value 
$\mathrm{Wu}$ and Shen (2013) found that positive customer emotion is related to employees' emotion expression. Therefore, the training of employees is not enough to make a positive emotion. The psychological aspect of employees determines employees' emotion expression.

For social value, one of the consumer needs is to be part of a particular social group. To strengthen the social status, consumers choose the products which will strengthen their social image. In this research, the hotel name, hotel classification, hotel reputation, brand class, and brand name are predicted to strengthen the social image of consumers (Levyda, 2017). The result is in Figure 8.

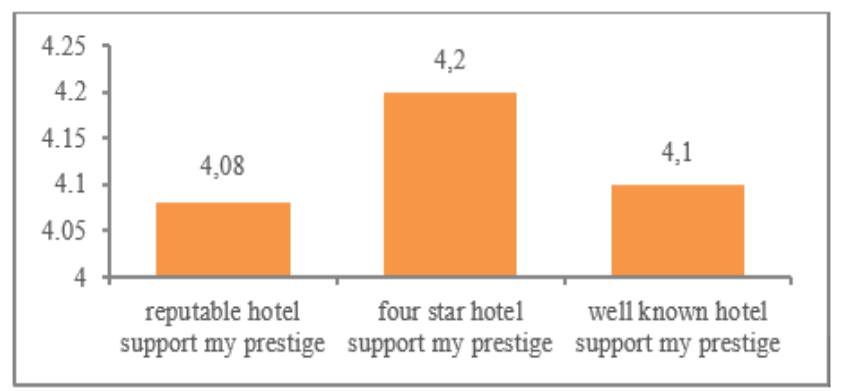

Figure 8 Social Value

The lower social value perceived is possibly due to ineffective brand management. For, consumers with prestige seeking behavior, the management should manage the brand. It likely helps the brand management.

In this research, the social value perceived by the guests is quite high. Vigneron and Johnson (1999) suspected that prestige seeking behavior was influenced by personal matters, price, quality, product uniqueness, and level of prestige. The personal matter is beyond the control of the company. Moreover, upgrading class of hotel requires major changes. Price supports consumer prestige, but if it is not supported by the quality and uniqueness of the product, it will backfire. However, one of the factors (quality) is under management control. Thus, quality is the best choice to support guest prestige. Furthermore, reputation is formed by long-term consistency of performance and good corporate communications (Gray \& Balmer, 1998). Therefore, many hotels are operated by using the franchise system as the shortcut.

With a range of 1 to 6 , the average of the perceived value is 4,366 for hypothesis testing. This means that the guests perceive a sufficient value from the four-star hotel in Jakarta. The standard deviation of the guests' perceived value is 0,569 . It indicates that the guests' perceived value is varied. Its standard error of parameter estimation is 0,0035 . It means that the variation of the parameter is low. The standard deviation and standard error indicate that the data are good. Statistical hypotheses in this research are in Table 2
Table 2 Statistical Hypotheses

\begin{tabular}{ll}
\hline $\mathrm{H}_{0}: \mu 1 \geq 5,15$ & $\begin{array}{l}\text { Guests in four-star hotels in Jakarta } \\
\text { have perceived superior value }\end{array}$ \\
\hline $\mathrm{H}_{\mathrm{a}}: \mu 1<5,15$ & $\begin{array}{l}\text { Guests in four-star hotels in Jakarta } \\
\text { have not perceived superior value }\end{array}$ \\
\hline
\end{tabular}

The student $t$-test is $-23,455$. This result is higher than the t-table so that the null hypothesis is rejected. Meanwhile, the alternative hypothesis is accepted with a $5 \%$ error rate. It means guests in four-star hotels in Jakarta have not perceived superior value.

\section{CONCLUSIONS}

Hotel guests have not perceived a superior value. Hotels should increase the value to win the competition and build long-term relationships with guests. To increase the value, the hotel manager needs to make a comprehensive plan, and determine priorities and the importance value for the guest. Priorities and the importance of value can be suggested as the future research.

\section{REFERENCES}

Akaegbu, J. B. (2013). An exploratory study of customers' perception of pricing of hotel service offerings in Calabar Metropolis, Cross River State, Nigeria. International Journal of Business and Social Science, 4(11), 295-301.

Anderson, J. C., \& Narus, J. A. (1998). Business marketing: understand what customers value. Harvard business review, 76, 53-67.

Badan Pusat Statistik Provinsi DKI Jakarta. (2014). Statistik hotel dan tingkat penghunian kamar hotel DKI Jakarta. Retrieved from .https://jakarta.bps.go.id/ backend/pdf_publikasi/Statistik-Hotel-dan-TingkatPenghunian-Kamar-Hotel-DKI-Jakarta-2014.pdf.

Badan Pusat Statistik. (2010). Occupancy rate of hotel room. Retrieved from https:/www.bps.go.id/ website/pdf_publikasi/Tingkat-Penghunian-KamarHotel-2010.pdf

Badan Pusat Statistik. (2012). Occupancy rate of hotel room. Retrieved from https://www.bps.go.id/ website/pdf_publikasi/watermark\%20_Tingkat $\% 20$ Penghunian\%20Kamar\%20Hotel\%202012.pdf

Barsky, J., \& Nash, L. (2002). Evoking emotion: Affective keys to hotel loyalty. The Cornell Hotel and Restaurant Administration Quarterly, 43(1), 39-46.

Batra, R., \& Ahtola, O. T. (1991). Measuring the hedonic and utilitarian sources of consumer attitudes. Marketing Letters, 2(2), 159-170.

Bojanic, D. C. (1996). Consumer perceptions of price, value and satisfaction in the hotel industry: An exploratory study. Journal of Hospitality \& Leisure Marketing, 4(1), 5-22.

Bowen, J. T., \& Shoemaker, S. (2003). Loyalty: A strategic commitment. Cornell Hotel and Restaurant Administration Quarterly, 44(5-6), 31-46. 
Boztepe, S. (2007). User value: Competing theories and models. International Journal of Design, 1(2), 5563.

Chen, C. F., \& Rothschild, R. (2010). An application of hedonic pricing analysis to the case of hotel rooms in Taipei. Tourism Economics, 16(3), 685-694.

Chen, Z., \& Dubinsky, A. J. (2003). A conceptual model of perceived customer value in e-commerce: A preliminary investigation. Psychology \& Marketing, 20(4), 323-347.

Cooper, D. R. \& Schindler, P. S. (2011). Business research methods. Singapore: Mc Graw-Hill. Inc.

Cravens, D.W. \& Piercy, N. F. (2009). Strategic marketing. New York: McGraw-Hill Irwin

Cronin, J. J., Brady, M. K., \& Hult, G. T. M. (2000). Assessing the effects of quality, value, and customer satisfaction on consumer behavioral intentions in service environments. Journal of Retailing, 76(2), 193-218.

Day, G. S. (1999). Market driven strategy: Processes for creating value. New York: Free Press.

Gray, E. R., \& Balmer, J. M. (1998). Managing corporate image and corporate reputation. Long Range Planning, 31(5), 695-702.

Gallarza, M. G., \& Saura, I. G. (2006). Value dimensions, perceived value, satisfaction and loyalty: An investigation of university students' travel behaviour. Tourism Management, 27(3), 437-452.

Haemoon, O. (2000). Diners' perceptions of quality, value, and satisfaction: A practical viewpoint. The Cornell Hotel and Restaurant Administration Quarterly, 41(3), 585-66.

Haksever, C., Chaganti, R., \& Cook, R. G. (2004). A model of value creation: Strategic view. Journal of Business Ethics, 49(3), 295-307.

Hirschman, E. C., \& Holbrook, M. B. (1982). Hedonic consumption: Emerging concepts, methods and propositions. The Journal of Marketing, 46(3), 92101.

Holbrook, M. B. (2006). Consumption experience, customer value, and subjective personal introspection: An illustrative photographic essay. Journal of Business Research, 59(6), 714-725.

Hosany, S., \& Martin, D. (2012). Self-image congruence in consumer behavior. Journal of Business Research, 65(5), 685-691.

Huber, F., \& Herrmann, A. (2000). Gaining competitive advantages through customer value oriented management. In American Marketing Association Conference Proceedings. American Marketing Association.

Jones, T. O., \& Sasser, W. E. (1995). Why satisfied customers defect. Harvard Business Review, 73(6), 88.

Koh, Y. L. (2008). Healing interior: Using Eastern design principles in hotel design (Doctoral Dissertation). Virginia Commonwealth University Interior Environments.

Levyda, L. (2017). What values are perceived by hotel guests?. International Journal of Services, Economics and Management, 8(1-2), 73-89.
Malhotra, N. K. (2012). Basic marketing research integration of social media. New Jersey: Pearson Prentice Hall.

Miladian, H., \& Sarvestani, A. K. (2012). A customer value perspective motivates people to purchase digital items in virtual communities. International Proceedings of Economics Development \& Research, 29, 225-230.

Parasuraman, A., \& Grewal, D. (2000). The impact of technology on the quality-value-loyalty chain: A research agenda. Journal of the Academy of Marketing Science, 28(1), 168-174.

Payne, A., \& Holt, S. (2001), Diagnosing customer value: integrating the value process and relationship marketing. British Journal of Management, 12, 159182.

Ravald, A., \& Grönroos, C. (1996). The value concept and relationship marketing. European Journal of Marketing, 30(2), 19-30.

Reid, R. D., \& Bojanic, D. C. (2010). Hospitality marketing management. New Jersey: John Wiley \& Sons.

Richard, C. M., Tse, P., Ling, L., \& Fung, F. (2000). Enhancement of maintenance management through benchmarking. Journal of Quality in Maintenance Engineering, 6(4), 224-240.

Sanchez, J., Callarisa, L., Rodriguez, R. M., \& Moliner, M. A. (2006). Perceived value of the purchase of a tourism product. Tourism Management, 27(3), 394409.

Sánchez-Fernández, R., \& Iniesta-Bonillo, M. Á. (2006). Consumer perception of value: Literature review and a new conceptual framework. Journal of Consumer Satisfaction, Dissatisfaction and Complaining Behavior, 19, 40-58.

Sánchez-Fernández, R., \& Iniesta-Bonillo, M. A., \& Holbrook, M. B. (2009). The conceptualization and measurement of consumer value in services. International Journal of Market Research, 51(1), 93-113.

Schiffman, L. G., \& Kanuk, L. L. (2010). Consumer behaviour. New Jersey: Pearson Education, Inc.

Sekaran, U., \& Bougie, R. (2010). Research methods for business: A skill building approach. United Kingdom: John Wiley \& Sons.

Sheth, J. N., Newman, B. I., \& Gross, B. L. (1991). Why we buy what we buy: A theory of consumption values. Journal of Business Research, 22(2), 159-170.

Shoemaker, S. (2003). Future of revenue management: The future of pricing in services. Journal of Revenue and Pricing Management, 2(3), 271-279.

Sirgy, M. J. (1982). Self-concept in consumer behavior: A critical review. Journal of Consumer Research, 9(3), 287-300.

Slater, S. F., \& Narver, J. C. (1994). Market orientation, customer value, and superior performance. Business Horizons, 37(2), 22-28.

Solomon, M. R. (2011). Consumer Behaviour: Buying, Having, Being. New Jersey: Pearson Education.

Smith, J. B., \& Colgate, M. (2007). Customer value creation: A practical framework. Journal of Marketing Theory and Practice, 15(1), 7-23. 
Sweeney, J. C., \& Soutar, G. N. (2001). Consumer perceived value: The development of a multiple item scale. Journal of Retailing, 77(2), 203-220.

Tam, J. L. (2004). Customer satisfaction, service quality and perceived value: An integrative model. Journal of Marketing Management, 20(7-8), 897-917.

Vigneron, F., \& Johnson, L. W. (1999). A review and a conceptual framework of prestige-seeking consumer behavior. Academy of Marketing Science Review, 1999(1), 1-15.

Williams, P., \& Soutar, G. N. (2009). Value, satisfaction and behavioral intentions in an adventure tourism context. Annals of Tourism Research, 36(3), 413438.

Woodruff, R. B. (1997). Customer value: The next source for competitive advantage. Journal of the Academy of Marketing Science, 25(2), 139-153.
Woodall, T. (2003). Conceptualising'value for the customer': An attributional, structural and dispositional analysis. Academy of Marketing Science Review, 2003, 1-42.

Wu, C. H. J., \& Liang, R. D. (2009). Effect of experiential value on customer satisfaction with service encounters in luxury-hotel restaurants. International Journal of Hospitality Management, 28(4), 586-593.

Wu, C. H. J., \& Shen, C. H. (2013). Factors affecting customer positive emotion and service relationrestaurants in hotel as examples. International Journal of Business Tourism and Applied Sciences, 1(2), 30-41.

$\mathrm{Wu}, \mathrm{S} . \mathrm{L}$. (2013). Innovative food safety strategies in a pioneering hotel. Food and Nutrition Sciences, 4(10), 1054-1059.

Zeithaml, V. A. (1988). Consumer perceptions of price, quality, and value: A means-end model and synthesis of evidence. The Journal of Marketing, 52, 2-22. 